\title{
MENTAL Distress DAMAGES FOR BREACH OF CONTRACT
}

\author{
Renee Holmes*
}

The common law has long held that damages for the mental distress suffered after a breach of contract are unrecoverable. Like all rules, a range of exceptions has developed to mitigate the severity of this rule. In this article the author argues that both the rule and its exceptions, being based neither in principle nor sound policy, have only created confusion in the law. The decision of the House of Lords in Farley v Skinner is analysed as a possible solution to this confusion, but is found to be unhelpful. The author concludes by calling for a principled revision of this area of the law in accordance with the usual principles of damages.

\section{INTRODUCTION}

Mental distress following a breach of contract is both a real and significant damage. For some aggrieved parties their intangible loss may far outweigh any financial loss they suffer. Unfortunately, the law does not find it easy to recognise such loss. At common law, the traditional position is that mental distress damages are not recoverable. Due to the harsh results of this blanket rule, the courts have developed limited exceptions to it. In practice these exceptions do not resolve the problem. Because of their narrow ambit, many cases deserving of compensation fall outside the exception and remain subject to the blanket ban. As courts have struggled to award damages in cases where they are perceived to be required, the existing law has been stretched and manipulated. This has resulted in the area becoming conceptually confused and unprincipled.

It is argued that the rule and its exceptions are unnecessary and needlessly complicate the area. Not only is the position contrary to usual damages principles, but it is not based on solid policy foundations and its conceptual underpinnings are unclear. This causes confusion and results in injustice. After outlining the relevant law and illustrating its problems, the results in practice will be shown through an analysis of New Zealand case law. The latest House of Lords decision will then be analysed for possible solutions. However, it is suggested that this decision only adds to the confusion. Not only does it fail to resolve the existing problems, but some of the reasoning is

* Submitted as part of the LLB(Hons) programme at Victoria University of Wellington (supervisor: David McLauchlan). 
internally contradictory and the distinctions drawn are unsustainable. It is contended that this case should not be followed in New Zealand.

Finally, it is suggested that this area urgently requires revision by the New Zealand Supreme Court. The Court should take the initiative to remedy the uncertainty by making claims for mental distress subject only to the usual principles of damages law. Until a principled and clear approach is enunciated by a higher court the problems will continue, and many complaints will be treated inconsistently and unfairly with significant damage going uncompensated.

\section{THE DEVELOPMENT OF UNPRINCIPLED PRINCIPLES}

\section{A The Rule in Addis v Gramophone Co Ltd}

The general rule at common law, laid down in Addis v Gramophone Co Ltd, ${ }^{1}$ is that damages for injured feelings cannot be recovered in an action for breach of contract. Although it has been argued that the decision has been wrongly interpreted, ${ }^{2}$ it is now accepted that it stands for the wider proposition. This results in many claimants being under-compensated for what can be real and serious loss.

The Addis rule is inconsistent with the established measure of contract damages. ${ }^{3}$ As stated in Robinson $v$ Harman, ${ }^{4}$ that is, that the plaintiff is entitled to be put in the same position as if the contract had been performed, so far as money can do it. ${ }^{5}$ However, under the Addis rule no damages can be awarded for mental distress. Therefore, Addis constitutes an exception to the general principle of contract damages.

For this reason, the rule is said to rest on policy foundations. ${ }^{6}$ However, the exact basis of that policy is far from clear. ${ }^{7}$ It is said that intangible loss is inherently too hard to quantify in monetary terms. However courts regularly quantify such loss in other areas of the law, ${ }^{8}$ and they are prepared

1 Addis v Gramophone Co Ltd [1909] AC 488 (HL).

2 Nelson Enonchong "Breach of Contract and Damages for Mental Distress" (1996) 16 OJLS 616, 628. The author argues that damages were denied because there was an alternative action in defamation or because the loss flowed not from the breach itself but from the manner of the breach.

3 Elizabeth MacDonald "Contractual Damages for Mental Distress" (1994) 7 JCL 134.

4 Robinson v Harman (1848) 1 Exch 850 Parke B.

5 Robinson, above n 4, 855.

6 M P Furmston "Damages - Diminution in Value or Cost of Repair? - Damages for Distress" (1993) 6 JCL $64,66$.

7 Enonchong, above n 2, 631.

8 For example in tort for nervous shock, or wrongful dismissal under the Employment Relations Act 2000. 
to place a monetary value on damage in situations that fall within an exception to the rule. ${ }^{9}$ It is further claimed that mental distress is not a foreseeable loss and therefore does not satisfy the remoteness requirement. However, it is apparent that in some cases mental distress is clearly foreseeable. ${ }^{10}$ Other rationales advanced include a reluctance to increase the costs of entering into contracts and an implied assumption that the plaintiff agrees to bear the risk. The above arguments do not stand up to close scrutiny and have been convincingly refuted. ${ }^{11}$ Therefore we are "left with a rule which rests on flimsy policy foundations and conceptually is at odds with the fundamental principle governing the recovery of damages."12

This area has become further complicated as courts have sought ways around such a harsh rule. In an effort to mitigate the effects of Addis, a number of limited exceptions have evolved. These have created further uncertainty and confusion.

\section{B Exceptions to the Addis Rule}

\section{Physical inconvenience and the "holiday" cases}

The first exception allows recovery for physical discomfort and mental distress arising directly from that discomfort. In Hobbs $v$ London and South Western Railway Co, the plaintiffs were able to recover for their physical inconvenience when a railway company, in breach of contract, failed to deliver them to the correct destination. ${ }^{13}$ It was held that the plaintiff could recover not only the price of the ticket but also for the inconvenience and physical discomfort of having to walk home. The Court distinguished between cases of mere vexation or annoyance and real physical discomfort. This must be correct, as discomfort flowing naturally from a breach of contract is foreseeable consequential loss and is damage that should be compensated. ${ }^{14}$ Since this case, damages awards for physical inconvenience have been relatively uncontroversial.

9 See Part II B Exceptions to the Addis Rule below.

10 D W McLauchlan "Mental Distress Damages for Breach of Commercial Contracts" (1997) 3 NZBLQ 130, 137.

11 See generally Bloxham v Robinson (1996) 7 TCLR 122, 147-151 (CA) Thomas J dissenting; Rowlands v Collow [1992] 1 NZLR 178, 205-209 (HC) Thomas J; A S Burrows "Mental Distress Damages in Contract - A Decade of Change" (1984) LMCLQ 119,132-33; Andrew Phang "The Crumbling Edifice? - The Award of Contractual Damages for Mental Distress" (2003) JBL 341, 341-356; Enonchong, above n 2, 631-632.

12 Baltic Shipping Co v Dillon (1993) 176 CLR 344, 362 Mason CJ. However his Honour upheld the general no recovery rule on the ground that such damage will seldom be so significant as to attract an award of damages.

13 Hobbs v London and South Western Railway Co (1875) LR 10 QB 111, 122, Blackburn J.

14 Hadley $v$ Baxendale (1854) 9 Exch 341; Victoria Laundry (Windsor) Ltd v Newman Industries Ltd [1949] 2 KB 528 (CA); The Heron II [1969] 1 AC 350 (HL). 


\section{Watts v Morrow}

The next exception to the Addis rule has been developed by the courts since the 1970's. These are the so called "holiday cases", although the exception has been utilised in other situations. Under this exception damages have been awarded where the object of the contract was to provide pleasure, peace of mind or sentimental benefit. Awards have been made in cases where a wedding photographer failed to perform his duties, ${ }^{15}$ where holidays did not meet the represented standard, ${ }^{16}$ and where a solicitor negligently failed to obtain a non-molestation order. ${ }^{17}$ It seems likely that the judges in these cases did not have a firm rule in mind and appeared to be using normal remoteness principles in order to achieve a just result. However, this apparently disparate line of cases was recast as a firm exception to Addis in Watts $v$ Morrow. ${ }^{18}$

In Watts, the plaintiffs purchased a holiday home in reliance on a surveyor's report. It transpired that the surveyor had been negligent. The plaintiffs were forced to carry out repairs at considerable cost. They also suffered significant stress and disappointment. Bingham LJ restated the rules for recovery of non-pecuniary damages as follows: ${ }^{19}$

A contract-breaker is not in general liable for any distress, frustration, anxiety, displeasure, vexation, tension or aggravation which his breach of contract may cause to the innocent party. This rule is not, I think, founded on the assumption that such reactions are not foreseeable, which they surely are or may be, but on considerations of policy.

But the rule is not absolute. Where the very object of a contract is to provide pleasure, relaxation, peace of mind or freedom from molestation, damages will be awarded if the fruit of the contract is not provided or if the contrary result is procured instead. If the law did not cater for this exceptional category of case it would be defective. A contract to survey the condition of a house for a prospective purchaser does not, however, fall within this exceptional category.

In cases not falling within this exceptional category, damages are in my view recoverable for physical inconvenience and discomfort caused by the breach and mental suffering directly related to that inconvenience and discomfort.

However, as the fact situation in Watts did not fall within the first exception the plaintiffs were unable to recover damages for their significant distress, although they were awarded some damages

15 Diesen $v$ Samson (1971) SLT (Sh Ct) 49.

16 Jarvis v Swan Tours Ltd [1973] 1 All ER 71 (CA); Jackson v Horizon Holidays Ltd [1975] 3 All ER 92 (CA).

17 Heywood $v$ Wellers [1976] 1 All ER 300 (CA).

18 Watts v Morrow [1991] 1 WLR 1421 (CA).

19 Watts $v$ Morrow, above n 18, 1445 Bingham LJ. 
under the second exception for physical inconvenience suffered during the time of repairs. The trial judge described the contract as falling within the first exception - the very object of the surveyor's contract was to provide the purchasers with peace of mind. However, the Court of Appeal described this as an "impossible" view. Although peace of mind may be incidental to a surveyor's contract, in this case there was no express promise to provide such a benefit. ${ }^{20}$

Both the trial judge and Bingham LJ's analysis of the nature of the surveyor's contract seem feasible. Certainly, it can be argued that since a house purchase is the largest transaction a normal purchaser will ever enter into, the object of the contract is to receive peace of mind that his or her purchase is sensible. On the other hand, the Court of Appeal's narrower view may be equally tenable. Which of these views is correct, on Bingham LJ's reasoning, depends on what was meant by his requirement for pleasure or peace of mind to be the "very object of the contract".

It is highly probable that in formulating this exception, Bingham LJ was addressing contracts where the bargain made was for some intangible mental benefit that cannot be measured in terms of economic loss. It is likely he had in mind cases such as Diesen $v$ Samson, ${ }^{21}$ where, due to the wedding photographer's breach of contract, the plaintiffs were left without any memories of their important day. In that case the only damages that could be awarded were for loss of the sentimental benefit of the photographs, as the deprivation of the bargain did not cause any economic loss. A similar situation occurred in Jarvis $v$ Swan Tours $L t d,{ }^{22}$ where untrue representations concerning a skiing holiday were made, with the result that the plaintiff did not enjoy his only two week holiday of the year. In such a case damages must be awarded for loss of the pleasurable experience contracted for, as what the plaintiff had really bargained for was an enjoyable two weeks, and that loss could not be compensated by economic loss damages. So it is apparent that damages for mental distress have to be given in these situations, because damages for economic loss cannot be awarded. ${ }^{23}$ Had the plaintiffs in Diesen and Jarvis not recovered damages for distress, there would have been no remedy at all for the breach of contract.

Therefore, in cases falling within Bingham LJ's first exception, the compensation is for loss of a bargain. The requirement for a mental benefit to be the very object of a contract is closely analogous to a requirement for a mental benefit in the contract to be a condition. Saying "the very object" of the contract is very like saying the "essence" of the contract. Consequently, in these cases compensation is in the nature of expectation damages for loss of the benefit contracted for, as opposed to consequential damages for the foreseeable harm caused by the breach. As a result, on

20 Watts v Morrow, above n 18, 1442 Ralph Gibson LJ.

21 Diesen $v$ Samson, above n 15, 49.

22 Jarvis $v$ Swan Tours Ltd, above n 16.

23 Francis Dawson "General Damages in Contract for Non-Pecuniary Loss" (1983) 10 NZULR 232, 247. 
this reasoning, it is correct that Watts should fall outside the exception, and recovery would be prevented by the Addis rule.

Unfortunately, the result of this formulation is that there is a class of potentially deserving cases where the plaintiff is denied a remedy for real damage suffered. These are cases, such as Watts, where the plaintiffs have suffered consequential loss, that is to say where foreseeable distress has resulted from the breach of contract. Damage naturally flowing from the breach, within the reasonable contemplation of the parties at the time the contract was made as likely to occur if the contract was breached, is firmly established as a legitimate ground of recovery. ${ }^{24}$ But in cases of mental distress, despite that damage satisfying the ordinary requirements for an award of contract damages, recovery is denied. Both expectation damages (to give the benefit of the bargain) and consequential damages (to repair the harm done by the breach) are required to put the plaintiff in the same position that he or she would have been in had the contract been performed. ${ }^{25}$ Therefore, failure to compensate consequential mental distress upon a breach of contract, as is the case under Bingham LJ's formulation, leaves the plaintiff under-compensated.

There is no logical or policy reason for denying recovery in these cases. The second exception allows recovery for consequential loss for physical inconvenience and for mental distress arising out of that inconvenience. As a result, Bingham LJ acknowledges that consequential loss is deserving of compensation. Any policy arguments which would rule out recovery for mental distress cannot be sustained as his Lordship is prepared to compensate mental distress either as loss of a bargain under the "objects" exception or as consequential loss under the second exception, as long as it accompanies physical inconvenience. In addition, it seems illogical to allow recovery for consequential loss where it is once removed from the breach (flowing from the physical inconvenience) but not when it results directly from the breach. The decision in Watts illustrates the unjust results that arise from applying the Addis rule to cases of consequential mental distress damage. Although the plaintiffs undoubtedly suffered significant distress, they were denied recovery.

Watts has been cited and applied in numerous cases, which illustrate the problems with denying recovery for simple mental distress as consequential damage. In Hayes $v$ Dodd a husband and wife team had purchased a premises for a motor repair business. ${ }^{26}$ Due to negligent advice from their solicitor about an access way that was crucial to the success of the venture, the business was forced to close down. The plaintiffs suffered significant distress, but were unable to recover as they did not fall within either of Bingham LJ's exceptions. "[T]he object of the contract was not comfort or

24 Hadley $v$ Baxendale, above n 14; Victoria Laundry (Windsor) Ltd v Newman Industries Ltd, above n 14; The Heron II, above n 14.

25 Dawson, above n 23, 236.

26 Hayes $v$ James and Charles Dodd (a firm) [1990] 2 All ER 815 (CA). 
pleasure, or the relief o[f] discomfort, but simply carrying on a commercial activity with a view to profit."27 With respect, this is a case where mental distress should have been compensated. ${ }^{28}$ It was foreseeable consequential damage flowing from a breach of contract. The plaintiffs were denied compensation for the extra harm that was caused by the defendant's breach.

In Knott $v$ Bolton an architect failed to carry out instructions to include a grand staircase and entranceway in his house design. ${ }^{29}$ Despite suffering significant disappointment and distress, the plaintiffs could not recover because the object of the contract was to design a house, not to provide pleasure. Once again, this result clearly left the plaintiffs under-compensated. The plaintiffs had spent a significant amount of money on the construction of their dream home; naturally they suffered significant distress when their wishes were not carried out. These decisions illustrate the problems with the existing law: it fails to allow recovery for straightforward consequential mental distress damage.

It would appear that the lower courts in England are increasingly stretching the exceptions to accommodate what they perceive to be deserving cases, regardless of the fact they clearly fall outside the established exceptions. Thus in Farley $v$ Skinner, ${ }^{30}$ Lord Steyn commented that: ${ }^{31}$

in the real life of our lower courts non-pecuniary damages are regularly awarded on the basis that the defendant's breach of contract deprived the plaintiff of the very object of the contract, viz pleasure, relaxation, and peace of mind. The cases arise in diverse contractual contexts, eg the supply of a wedding dress or double glazing, hire purchase transactions, landlord and tenant, building contracts, and engagements of estate agents and solicitors.

It is very difficult to understand how awards can be made in some of these situations in accordance with authority. It seems obvious that the very object of a contract for hire purchase is not pleasure or peace of mind. A similar situation exists in other common law jurisdictions.

The leading authority in Australia is Baltic Shipping Co v Dillon. ${ }^{32}$ In that case the High Court accepted that mental distress damages are not generally available. However, this rule is subject to an exception where there is an express or implied term for the provision of pleasure. ${ }^{33}$ As with the

27 Hayes $v$ Dodd, above n 26, 824 Staughton LJ.

28 See Rowlands $v$ Collow, above n 11, 207 Thomas J, pointing out the difference between a husband and wife team whose consequential distress is clearly foreseeable and a "impersonal shipping magnate" whose loss would fall outside of the remoteness principles.

29 Knott $v$ Bolton (1995) 11 Construction LJ 375 (CA).

30 Farley v Skinner [2001] 3 WLR 899 (HL).

31 Farley v Skinner, above n 30, 907 para 20 Lord Steyn.

32 Baltic Shipping Co v Dillon, above n 12.

33 Baltic Shipping, above n 12, 405 McHugh J. 
first exception in Watts, this exception appears to relate to something analogous to a condition. Following this decision, contradictory results are being reached in the Australian lower courts. In Manolakis $v$ Galaxy Homes Pty Ltd anxiety was suffered as a result of defective building work. ${ }^{34}$ Damages for mental distress were awarded on the basis that the damage was reasonably foreseeable, despite Baltic Shipping Co being cited. But, as the contract was for building work, it could not be said that a mental benefit was at the heart of the contract and this case should not have been accommodated under the exception. On the other hand in Dagenham Nominees Pty Ltd $v$ Shanks, ${ }^{35}$ damages were denied for loss of enjoyment at being unable to race a yacht due to defective workmanship constituting a breach of contract. Even though this was arguably a more suitable case to fall within the exception than Manolakis, the Court ruled that the object of the contract was not pleasure or peace of mind so it fell outside the Baltic Shipping Co exception. ${ }^{36}$

Canada has encountered similar problems. Mason $v$ Westside Cemeteries Ltd involved breach of a contract of bailment when Westside Cemeteries lost the ashes of the plaintiff's parents. ${ }^{37}$ Molloy $\mathrm{J}$ in the Ontario Court of Justice undertook a review of the Canadian law on mental distress damages for breach of contract. This revealed a number of conflicting authorities, and he stated:38

it is difficult to determine from these cases what principles should be applied in determining the recoverability of mental distress damages. While some courts awarded such damages, others refused to do so in the absence of wilful misconduct by the defendant.

Molloy $\mathrm{J}$ went on to award $\$ 1,000$ for mental distress. This is in conflict with the earlier decision of the Supreme Court of British Colombia in McNeil v Forest Lawn Memorial Services $L t d,{ }^{39}$ where in breach of contract the plaintiffs' daughter was cremated before the parents had viewed the body. In that case Gould J declined to award damages for mental distress as such damages were not available for breach of contract as a matter of law. These results are inconsistent and illustrate the different perceptions of the rules prevalent in the Commonwealth courts. This is perhaps unsurprising given that there is no legitimate justification for preventing recovery for consequential mental distress.

\footnotetext{
34 Manolakis \& Manolakis v Galaxy Homes Pty Ltd [2003] SADC 80 Anderson J.

35 Dagenham Nominees Pty Ltd v Shanks [2002] SADC 169 David J.

36 Dagenham Nominees, above n 35, para 58.

37 Mason v Westside Cemeteries Ltd (1996) 135 DLR ( $\left.4^{\text {th }}\right) 361$ (Ontario Court Gen Div).

38 Mason v Westside Cemeteries Ltd, above n 37, 378 Molloy J.

39 McNeil v Forest Lawn Memorial Services Ltd (1976) 72 DLR ( $\left.3^{\text {rd }}\right) 556$ (SC British Columbia).
} 


\section{NEW ZEALAND}

It is unfortunate that the New Zealand courts have been inclined to follow the approach of the English courts. This has resulted in a contradictory approach to the question of damages for mental distress in the Court of Appeal. With the confusion evident in decisions of the House of Lords and conflicting decisions in the New Zealand Court of Appeal, there is little wonder that no coherent principle can be found amongst the cases heard at High Court and District Court level.

\section{A Conflicting Authorities}

\section{Remoteness and commercial contracts}

It initially appeared that New Zealand courts were moving towards a remoteness test for the award of mental distress damages. ${ }^{40}$ In Snodgrass $v$ Hammington, ${ }^{41}$ house purchasers recovered $\$ 20,000$ for anxiety after a misrepresentation about subsidence problems on the property. The Court of Appeal said little by way of justification of the award, but awarded damages because the loss sustained was not too remote.

However, following Hayes $v$ Dodd, damages for mental distress are not recoverable for breach of commercial contracts. ${ }^{42}$ In Mouat $v$ Clarke Boyce damages were awarded to the plaintiff for mental distress when a solicitor acted negligently in a mortgage transaction. ${ }^{43}$ But Cooke $\mathrm{P}$ added the proviso that: ${ }^{44}$

The Courts have stopped short of giving stress damages for breach of ordinary commercial contracts.

Stress is an ordinary incident of commercial or professional life. Ordinary commercial contracts are not intended to shelter the parties from anxiety.

The fallacy of this argument has been convincingly refuted elsewhere, ${ }^{45}$ and it is unnecessary to traverse it again. However, it is clear that there is no valid distinction, for the purposes of consequential mental distress damages, between commercial and non-commercial contracts. Fears that allowing damages in such cases will open the floodgates are unfounded as in these cases

40 See Rowlands $v$ Collow, above n 11; Snodgrass $v$ Hammington [1996] ANZ ConvR 598 (CA).

41 Snodgrass $v$ Hammington, above n 40, 598 Penlington $\mathrm{J}$ for the Court.

42 See Watson v Dolmark Industries Ltd [1992] 3 NZLR 311, 316 (CA) Cooke P; Horsburgh v New Zealand Meat Processors Industrial Union of Workers [1988] 1 NZLR 698, 703 (CA) Cooke P; Whelan $v$ Waitaki Meats Ltd [1991] 2 NZLR 74, 89 (HC) Gallen J; Mouat v Clark Boyce [1992] 2 NZLR 559, 569 (CA) Cooke P.

43 Mouat v Clarke Boyce, above n 42.

44 Mouat v Clark Boyce, above 42, 569 Cooke P.

45 See generally Bloxham v Robinson, above n 11, 147 Thomas J dissenting; Rowlands v Collow, above n 11, 207 Thomas J; Baltic Shipping Co v Dillon, above n 12, 365 Mason CJ; McLauchlan, above n 10; Phang, above n 11, 354 . 
damages will most often be ruled out on the de minimis principle and it is obvious that corporations, not being natural persons, are unable to suffer distress and could not recover such damages. ${ }^{46}$ Concerns that allowing recovery may lead to the adoption of "the United States practice of huge awards" 47 is unjustified as it has been consistently been emphasised by the courts that awards for mental distress should be kept modest. ${ }^{48}$

\section{The adoption of Watts v Morrow}

Accordingly, it appeared that mental distress damages were recoverable, subject to usual remoteness principles, for all but commercial contracts. However, in Bloxham v Robinson the Court of Appeal appeared to backtrack, once again adopting English precedent. ${ }^{49}$ The case concerned a contract to buy into a dentistry practice. In breach of contract the defendant failed to transfer the required number of patients to the plaintiff, who was purchasing half of the practice including half of the "goodwill". As a result, the business was not as profitable as it was thought to be. $\mathrm{Mr}$ Bloxham suffered significant distress and embarrassment because the business was not as successful as it should have been.

The majority in the Court of Appeal cited Hayes $v$ Dodd and more significantly, Watts, with approval, and declined to award damages for distress. ${ }^{50}$ It has been correctly suggested that this decision is per incuriam. ${ }^{51}$ This is clearly inconsistent with the earlier rulings of the Court in Mouat and Snodgrass, which were not referred to. If Watts was the law in New Zealand the plaintiffs in those cases could not have succeeded in their claims, as the object of the contracts could not have been said to be pleasure or peace of mind. ${ }^{52}$ It may be that the majority, as Thomas $\mathrm{J}$ later claimed, never intended to actually adopt Watts into New Zealand law. ${ }^{53}$ However, as the Court of Appeal has yet to re-examine the area, it would appear that Watts represents the current law.

46 McLauchlan, above n 10, 142.

47 Hayes $v$ James and Charles Dodd (a firm), above n 26, 823 Staughton LJ.

48 Rowlands v Collow, above n 11, 207 Thomas J; Andrews v Parceline Express Ltd [1994] 2 ERNZ 385, 397 (CA) Tipping J; Bloxham v Robinson, above n 11, 150, Thomas J dissenting; Mouat v Clark Boyce, above $\mathrm{n}$ 42, 559, 569 (CA) Clarke P. But it is questionable whether sums such as \$20,000 in Snodgrass, \$25,000 in Mouat, and the \$20,000 Thomas J proposed in Bloxham are really modest awards.

49 Bloxham v Robinson, above n 11, 122.

50 Bloxham v Robinson, above n 11, 138 McKay and Temm JJ.

51 McLauchlan, above n 10, 143.

52 McLauchlan, above n 10, 143.

53 Accident Rehabilitation and Compensation Insurance Corporation v Kelly (20 March 1997) CA298/96 Thomas J. 


\section{B The Practice of the Courts}

Not surprisingly, given the conflicting authorities at the appellate level, the lower courts' decisions do not show any consistent principle on which non-pecuniary damages are awarded. The difficulties are caused by confusion as to what the law actually is and uncertainty as to the application of the three possible approaches that may be adopted. Given the state of the authorities and problems with both the Watts approach and the commercial/non-commercial contract distinction, this is unsurprising.

\section{The remoteness approach}

Some judges have awarded damages for mental distress on pure remoteness principles. ${ }^{54}$ Cotterell \& Thomas $v$ Windsor concerned a contract for the sale of a property that was breached when the defendant purchaser failed to settle. ${ }^{55}$ The plaintiffs were put under considerable stress, having committed to bridging finance for the purchase of a new property. Master Lang awarded various damages for the financial loss suffered by the plaintiffs. He awarded a further $\$ 6,000$ in general damages for mental distress. The Master commented that counsel had been unable to refer him to any authority dealing with similar circumstances. He went on to quote an article that, ${ }^{56}$ he says, suggests that such damages are "routinely awarded in NZ courts", ${ }^{57}$ and the 1989 case of Innes $v$ Ewing. ${ }^{58}$ On the basis of this limited authority the Master felt himself to be justified in stating that "it is now clear that damages for inconvenience and distress are recoverable if they are of a kind within the reasonable contemplation of the parties when they entered into the contract." 59

Even leaving aside the dubious assertion of lack of authority, this proposition appears startling. On the basis of Watts this would not be an appropriate case for damages because the sale of a house is not a contract in which the very object is to provide pleasure or peace of mind. It was a case of consequential loss that, as explained above, does not fall within either of the Watts categories.

A similar approach to that in Cotterell was taken in Battersby $v$ Foundation Engineering Ltd. ${ }^{60}$ A surveyor negligently failed to report, in breach of a contractual duty of care, that the property

54 See North $v$ Wright, Adams, James \& Longford Holdings (22 October 1999) HC WN CP315/96 Wild J; Cotterell \& Thomas $v$ Windsor (8 May 2003) HC AK CP 358-IM02 Master Lang; Battersby v Foundation Engineering Ltd (5 July 1999) HC AK CP26/97 Randerson J.

55 Cottrell \& Thomas $v$ Windsor, above $\mathrm{n} 54$.

56 McLauchlan, above n 10, 131.

57 Cotterell \& Thomas $v$ Windsor, above 54, para 50 Master Lang. But note that the article was not focused on this problem but on the commercial/non-commercial contract distinction.

58 Innes $v$ Ewing [1989] 1 NZLR 589 (HC) Eichelbaum J.

59 Cotterell \& Thomas $v$ Windsor, above n 54, para 52 Master Lang.

60 Battersby v Foundation Engineering Ltd, above n 54. 
being purchased was in danger of subsidence. The purchasers were awarded $\$ 20,000$ for mental distress. This case is indistinguishable from Watts and the result is inconsistent with that decision.

\section{The commercial contract distinction}

In contrast to the above approach, some cases have continued to follow the commercial/noncommercial distinction laid down in Mouat. ${ }^{61}$ But to exacerbate matters, there is disagreement as to what constitutes a commercial contract for this purpose. In Hames $v$ Gray, ${ }^{62}$ Pankhurst $\mathrm{J}$ held that a purchase of a deer farming business was not a commercial contract, because the farm also contained a dwelling house. His Honour upheld an award of $\$ 3,000$ for mental distress despite the anxiety relating to business matters.

On the other hand, in Skinner $v$ Leaf, mental distress damages were declined. ${ }^{63}$ That case concerned breach of a bailment contract over a herd of cows for share milking by a married couple. Hammond J stated "[o]f course these were transactions of a commercial character, in respect of which our courts have traditionally not made awards of the kind sought". ${ }^{64}$ Hames also appears to be inconsistent with Anderson $v$ Davies, ${ }^{65}$ and Cleaver $v$ Dallimore, ${ }^{66}$ where mental distress damages were refused on the grounds that the contract related to a sale of a business and was, therefore, a commercial contract.

\section{The Watts approach}

However, some District Court and High Court judges have, following Bloxham, applied Watts. ${ }^{67}$ In Griffiths $v$ ASB ${ }^{68}$ an unauthorised transfer of funds by ASB was found to be a breach of contract. It was held that Mrs Griffiths could not recover damages for mental distress consisting of hardship and change of lifestyle because pleasure and peace of mind was not the very object of the contract.

61 See Anderson v Davies [1997] 1 NZLR 617 (HC) Paterson J; Skinner v Leaf (27 March 2001) HC Ham A94/00 Hammond J; Ave v Galt [1999] DCR 146 Cadenhead J; Stevenson Precast Systems Ltd v Kelland (9 August 2001) HC Ak CP303-SD01 Tompkins J; Hansen v Young [2003] 1 NZLR 83 (HC) Wild J; Cleaver v Dallimore (9 August 2000) HC Dun CP17/00 Master Venning; Hames v Gray (24 July 2000) HC Dun AP3/00 Panckhurst J.

62 Hames $v$ Gray, above $n 61$.

63 Skinner $v$ Leaf, above n 61.

64 Skinner v Leaf, above n 61, para 61 Hammond J.

65 Anderson v Davies, above n 61.

Cleaver v Dallimore, above n 61.

67 See Clarence Holdings v Mt Albert Television (18 August 2000) HC AK CP12/97 Laurenson J; Griffiths v ASB (10 April 2000) HC Ak CP346/92 Tompkins J; McLeod v Anderson [2003] DCR 476 Judge Cadenhead.

68 Griffiths v ASB, above n 67. 
On the basis of Watts this is clearly correct but it is inconsistent with Snodgrass. Similarly, in McLeod $v$ Anderson, ${ }^{69}$ a sale of an opal that did not meet the represented quality did not come within either of the Watts exceptions and the plaintiff was unable to recover mental distress damages. If these cases had been heard by the judges in Cotterell or Battersby the result may have been different as the loss in both cases was clearly foreseeable.

It is clear that the three approaches being utilised are inconsistent. Therefore, some complainants may recover damages under a remoteness test, while some more serious losses go uncompensated when the narrower test in Watts, or the commercial/non-commercial distinction is applied. This is despite the fact that the damage may have been clearly foreseeable and would have resulted in a damages award under the remoteness approach. This creates inconsistency in recovery of damages for mental distress. This position is highly unsatisfactory and a coherent restatement of the law by the Supreme Court is urgently required.

\section{FARLEY V SKINNER: THE HOUSE OF LORDS APPROACH}

In 2002 the House of Lords had the opportunity to re-evaluate the availability of damages for mental distress when, in that year, three cases reached the House. Johnson $v$ Unisys Ltd was an action for wrongful dismissal. ${ }^{70}$ Although their Lordships dismissed the action, they showed some sympathy for the claim of damages for distress. They acknowledged that there may be an action for breach of an implied term of trust and confidence that could possibly sound in non-pecuniary damages. ${ }^{71}$ However, the plaintiff could not recover because it would undermine the statutory regime set up by Parliament to govern the area. ${ }^{72}$ Alternatively, it was said that even if such action was available, in this case the plaintiff's loss was too remote. ${ }^{73}$

Johnson $v$ Gore Wood was a strike-out application in the course of proceedings against negligent solicitors. ${ }^{74}$ The plaintiff's company, as a result of the defendant's negligence, had gone bankrupt with the result that the plaintiff suffered alleged significant stress and change in lifestyle. Despite his real distress, loss of personal relationships and transformation from wealthy businessman to social welfare beneficiary, the House of Lords struck out the claim and upheld the Addis rule.

69 McLeod v Anderson, above n 67.

70 Johnson v Unisys Ltd [2003] 1 AC 518 (HL).

71 Johnson $v$ Unisys Ltd, above n 70, para 28 Lord Steyn.

72 Johnson $v$ Unisys Ltd, above n 70, para 58 Lord Hoffman. But note that a different result would be reached in New Zealand where the plaintiff could have recovered under the Employment Relations Act 2000.

73 Johnson v Unisys Ltd, above n 70, para 29 Lord Steyn.

74 Johnson v Gore Wood \& Co (a firm) [2002] 2 AC 1 (HL). 
Lord Cooke dissented and would have allowed the case to go to trial. Recovery for breach of commercial contracts was ruled out, but in this case Mr Johnson's claim was "more akin to the physical inconvenience and discomfort referred to in Bingham LJ's third paragraph." 75 With respect, this represents a significant straining of the Watts category. Although the change in lifestyle and living conditions could be seen as physical inconvenience, this misrepresents the underlying thrust of the claim, which was for significant mental distress. This was not the kind of situation that was envisaged by Hobbs and the claim lacked the requisite promise of a mental benefit that would have allowed it to fall within the Watts "object" exception. Although there is no doubt that the plaintiff should have been entitled to damages for his consequential distress, Lord Cooke was forced to strain principles to reach his desired result. Once again the rule and its exceptions left a plaintiff uncompensated and resulted in straining the applicable principles in an attempt to circumvent the rule and allow recovery for consequential mental distress.

The third case in the trilogy is Farley $v$ Skinner. ${ }^{76}$ The House of Lords was dismayed that the case had appeared to cause such immense difficulties and they set out to resolve the confusion in the area. Lord Scott commented that "it is highly desirable that your Lordships now resolve the present angst on this subject and avoid the need in the future for relatively simple claims, such as $\mathrm{Mr}$ Farley's, to have to travel to the appellate courts for a ruling."77 However, due to an insistence on approving Watts and a desire to promote the decision in Ruxley Electronics and Construction Ltd v Forsyth, ${ }^{78}$ the Court refused to allow recovery for mental distress damages on the basis of usual contract principles. Unfortunately, far from resolving confusion in the area, it appears this decision has only compounded it.

The fact situation, as noted by Lord Scott, was simple. ${ }^{79}$ Mr Farley wanted to purchase a country estate. He was interested in a property in Surrey and engaged Mr Skinner to survey the property. He particularly stressed his desire for a peaceful retreat and asked Mr Skinner specifically to investigate the level of noise as the property was close to Gatwick airport. In his report $\mathrm{Mr}$ Skinner stated his opinion that the property would not be overly affected by aircraft noise. In reliance upon this, Mr Farley purchased the property and undertook extensive and expensive renovations. Shortly after he moved into the property he found that it was situated close to the Mayfield stack, where planes circled while waiting to land. As a result the property was affected by noise, and this interfered with Mr Farley's enjoyment of his property. He commenced litigation

\footnotetext{
5 Johnson v Gore Wood, above n 74, 49 Lord Cooke.

76 Farley v Skinner, above n 30.

77 Farley v Skinner, above n 30, para 74 Lord Scott.

78 Ruxley Electronics and Construction Ltd v Forsyth [1996] AC 344 (HL).

79 Farley v Skinner, above n 30, para 62 Lord Scott.
} 
claiming damages for the loss of the value of the property and general damages for distress and inconvenience.

At trial, Barker $\mathrm{J}$ found that Mr Skinner had been negligent in preparing the report. He further found that Mr Farley had purchased the house in reliance on the report and had he known of the noise he would not have bought the property. His Honour declined damages for diminution in the value of the property, as the property was not worth any less than what he had paid for it, despite the noise. However, the Judge recognised that the noise significantly interfered with Mr Farley's enjoyment of the property and awarded general damages for loss of amenity. ${ }^{80}$ The Court of Appeal overturned the award. The majority applied Watts and held damages for mental distress could not be recovered. It was not a contract where the very object was the provision of peace of mind or pleasure, and as a result it remained subject to the Addis rule. ${ }^{81}$ As there was no economic loss, $\mathrm{Mr}$ Farley was not entitled to any damages. On appeal the House of Lords unanimously overturned the Court of Appeal's decision and restored Barker J's award.

\section{A Very Object of the Contract to Provide Pleasure}

Although their Lordships were unanimous in holding that the case fell under Bingham LJ's first exception, different explanations for the basis of the award were put forward.

\section{Major or important object of the contract}

Lord Steyn, Lord Clyde and Lord Hutton took a similar view. They were anxious to retain the rule that damages for mental distress were not generally available and they approved the Watts "object" exception, with a minor extension. For mental distress to be recoverable it had to be the object of the contract. However, it was enough that it was an important or major object. ${ }^{82}$ In the case of Farley it was, as there was a specific request to investigate the noise. In communicating the request, "the plaintiff made it crystal clear to the surveyor that the impact of aircraft noise was of importance to him." 83 Damages had to be available where, although mental benefits were not the very object of the contract, they were an important part of it. If this were not the case, the result would depend on whether there was a separate contract or merely a general retainer, which is merely "a matter of form not substance". ${ }^{84}$ It was on this basis that Watts was distinguished but still approved.

80 Cited in Farley v Skinner, above n 30, paras 10-11 Lord Steyn.

81 Skinner v Farley [2000] Lloyds Rep 516 (CA).

82 Farley v Skinner, above n 30, para 24 Lord Steyn; para 41 Lord Clyde; para 54 Lord Hutton.

83 Farley $v$ Skinner, above n 30, para 18 Lord Steyn.

84 Farley v Skinner, above n 30, para 24 Lord Steyn. 
This approach continues to require an express term of the contract to be for the provision of pleasure or peace of mind, an implied term being an insufficient ground to recovery. This is a formalistic distinction that may create strange results. It is hard to understand why damages will be recoverable when there is a specific request but not where a matter of particular importance is known to both parties, but unspoken. Surely in Watts the surveyor would have been aware that, if the roof was faulty and would have to be replaced at great cost, it would be of particular importance to the plaintiffs to be informed of this. It was obviously of great importance in both Watts and Farley that they were provided with accurate information with which they could make an informed choice about their purchase. It seems strange that despite the surveyor being aware of the importance of the information in both cases, damages will only be recoverable if the plaintiff has made their piece of mind an important part of the contract by a specific request, and not if the loss is merely reasonably foreseeable to the surveyor. As one commentator has noted, whether or not damages will be awarded may depend on whether the complainant has had legal advice and knew of the requirement to make the surveyor specifically aware of matters of particular importance. ${ }^{85}$

This small extension to the Watts exception does not remedy the problems in the area discussed earlier. Consequential mental distress remains uncompensated, even under this expanded view, and this will continue to cause problems as the courts now try to stretch this new criterion to fit deserving cases.

\section{The "Ruxley" approach}

Lord Scott adopted a more radical approach. It is necessary to examine his speech in some detail since it has been argued that it "will prove to be the most significant and beneficial for the future development of the law in this area."86 His approach turns on an interpretation of Ruxley Electronics v Forsyth. ${ }^{87}$

In Ruxley, the plaintiff contracted to build a pool for the defendant. After some initial changes it was agreed that the pool would be built to a depth of seven foot six inches. When it was finished it was only six foot, but still safe to dive into. The defendant counterclaimed on the plaintiff's successful action to recover payment. He sought diminution in value, or alternatively, reinstatement or cost of the cure of the pool at $£ 21,000$. The trial Judge found that there was no diminution in value as the pool was worth the same as it would have been if it had been built to the specified depth. He also refused to award the cost of reinstatement - the cost being out of all proportion to the benefit to be gained. The Judge did, however, award £2,500 in damages for loss of amenity.

85 Ewan McKendrick and Martin Graham "The Sky's the Limit: Contractual Damages for Non-Pecuniary Loss: Farley v Skinner" (2002) LMCLQ 161, 163.

86 David Capper "Damages for Distress and Disappointment - Problem Solved?" (2002) 118 LQR 193, 194.

87 Ruxley Electronics, above n 78. 
The Court of Appeal reversed the decision and substituted an award of the cost of reinstatement. The House of Lords disagreed. Their Lordships held that reinstatement could not be awarded where it was unreasonable, contrary to common sense, out of all proportion to the benefit to be gained or would give the defendant a "windfall". ${ }^{8}$ They restored the trial Judge's ruling.

As the House of Lords merely restored the trial decision, there was little discussion on the loss of amenity award. Lord Lloyd cited Addis for the proposition that in general, damages cannot be recovered for injured feelings. However, in his opinion, the award fell under the "objects" exception. He stated that "if it involves a further inroad on the rule in Addis v Gramophone then so be it. But I prefer to regard it as a logical application or adaptation of the existing exception to a new situation."89 With respect, it is hard to see how the very object of a building contract is to provide pleasure or peace of mind, ${ }^{90}$ or how an exception normally applied to disappointed holiday expectations or continued harassment due to a solicitor's negligence can be properly applied to a construction case. Pleasure may be incidental and naturally flow from the construction contract, but pleasure could not be said to be the very object of the contract. This was not an appropriate case to fall under the Watts exception.

Lord Mustill advocated a wider view of loss. In his opinion the loss of a personal preference, even if no economic damage is caused, is a legitimate loss and one that ought to be compensated. ${ }^{91}$ This is part of a wider debate over what has been called an ambiguity in contract damages - whether damages should compensate loss of performance or loss of economic value. ${ }^{92}$ The compensation of consumers for benefits over and above the financial gain that they have contracted for has been called the consumer surplus. ${ }^{93}$ Ruxley appears to have come to stand for an enlarged conception of the loss that will be recognised by the law. ${ }^{94}$ However, it is important to note that this is not a new measure of contract damages. It is an argument for a wider notion of what is a loss. Damages are still limited to what the plaintiff has actually lost, which must always be proven, but it is recognised that in consumer contracts the loss may not be capable of being measured by economic loss alone. Lord Scott's approach has its roots in this notion.

88 Ruxley Electronics, above n 78, 367 Lord Lloyd.

89 Ruxley Electronics, above n 78, 374 Lord Lloyd.

90 Harvey McGregor McGregor on Damages (16 ed, Sweet \& Maxwell, London, 1997) para 104.

91 Ruxley Electronics, above n 78, 360 Lord Mustill.

92 Brian Coote "Contract Damages, Ruxley, and the Performance Interest" (1997) 56 CLJ 537, 540.

93 Donald Harris, Anthony Ogus and Jennifer Phillips "Contract Remedies and the Consumer Surplus" (1979) 95 LQR 581.

94 Ewan McKendrick "Breach of Contract and the Meaning of Loss" (1999) 52 CLP 37, 44. 
In Lord Scott's view, Ruxley can be used to award damages whenever a person has been deprived of a contractual benefit that would have been of value to them and cannot be compensated in any other way. ${ }^{95}$ This argument contains serious flaws and a close reading of Lord Scott's speech reveals serious conceptual inconsistencies.

The first serious objection to this argument is that, even if accepted, it is not applicable to Farley at all. In Farley there was no contractual entitlement to a result. All Mr Farley was entitled to was the exercise of reasonable skill and care. There was no basis for awarding damages for loss of contractual entitlement because he was not entitled to an estate unaffected by noise; he was only entitled to information provided with reasonable skill and care. Therefore, Mr Farley could not recover damages under Ruxley because there was no loss of contractual entitlement to be compensated.

Nevertheless, this is not to say that Mr Farley ought not to have recovered damages at all. $\mathrm{Mr}$ Farley had suffered consequential damage as a result of the breach of contract. In cases of consequential damage it makes no difference if there has been a breach of a warranty or of a duty of care, ${ }^{96}$ because the award does not relate to compensation for a lost benefit, which logically requires a promise to achieve a certain result. But it is compensation for the additional consequences and harm caused by the breach of contract. Consequential damages should, therefore, be available whether or not a specific outcome is promised.

This distinction between a warranty and a duty of care takes on a fundamental difference when evaluating expectation or loss of contractual entitlement damages. These types of damages are designed to give the plaintiff the benefit of the bargain. The defendant should be liable to compensate for loss of the result that was promised, but was not provided. However, in contractual duty of care cases, all the plaintiff has bargained for is the exercise of reasonable skill. The defendant has not given any promise of an end result, so he or she cannot be made to pay compensation for loss of a result bargained for when there has been no such promise. Therefore, in Farley, damages cannot be given to put the plaintiff in the position he or she would be in if there had been no noise, because he or she was never entitled to an estate without noise. Lord Scott's "Ruxley" damages are therefore not applicable to this case.

This misunderstanding of the nature of the promise is reflected in latter parts of the speech. Lord Scott described the unsuccessful economic loss claim as being for the difference between the value of the property as represented and the actual value of the property. With great respect, this is incorrect. Awarding the plaintiff the represented value would be giving damages as if there had been a warranty that there was no noise. The plaintiff had no such contractual guarantee; he only had a right to the exercise of reasonable skill and care. Therefore, the plaintiff is not entitled to

95 Farley v Skinner, above n 30, para 79 Lord Scott.

96 Farley v Skinner, above n 30, para 25 Lord Steyn; para 43 Lord Clyde; para 53 Lord Hutton. 
reinstatement or represented value less the actual value of the property. ${ }^{97}$ The proper calculation would be the difference between price paid and actual value. This is because the plaintiff's claim is not an expectation claim of "you promised the property was worth $£ x$, so I need compensation to that level to put me in the position I would have been in had the contract been performed". It is only a reliance claim of "you were negligent and because of that I purchased a property I wouldn't have otherwise and because of that I have suffered a loss". In addition, Lord Scott claimed that this was the calculation applied in Watts, ${ }^{98}$ but in that case the plaintiffs were actually awarded the difference between the price paid and the actual value of the property. ${ }^{99}$

Further, Lord Scott's application and classification of "Ruxley" damages to other cases does not conform to his own statement of the rules. The rule, as stated by him, allows such damages to be awarded when there is no other method of compensating the promisee. ${ }^{100}$ However, he claims that "Ruxley" damages can be recovered in cases where damages could be recovered as consequential loss under the physical inconvenience exception, ${ }^{101}$ so there is another method of compensating the loss. Further, he claims Ruxley damages were awarded in cases where it is clear that the award in the case was intended to compensate consequential loss, not loss of a contractual entitlement. ${ }^{102}$ Therefore, in those cases there was another method of compensating the plaintiff, so his classification contradicts his requirement that there is no other method of compensation available. In addition, he claims recovery was under the physical inconvenience exception or was ruled out on policy grounds in cases where it is hard to understand why they are not classified as Ruxley cases. These cases involve loss of contractual entitlement in a situation where there is no other method of compensation available so it clearly falls within Lord Scott's formulation of Ruxley damages. ${ }^{103}$ So

97 D W McLauchlan "Recovery of Lost Profits for 'Reasonable Grounds' Misrepresentations" (2002) 8 NZBLQ 110, 114

98 Farley v Skinner, above n 30, para 81 Lord Scott.

99 Watts v Morrow, above n 18, 1443 Bingham LJ.

100 Farley v Skinner, above n 30, para 79 Lord Scott.

101 Lord Scott classifies Hobbs v London and South Western Railway Co, above n 13; Jarvis v Swan Tours, above n 16; Jackson v Horizon Holidays Ltd, above n 16; Knott v Bolton, above n 29 as "Ruxley" cases. However, in these cases damages could have been awarded for consequential loss.

102 In Jarvis $v$ Swan Tours, above n 16, the award was twice the cost of the holiday. Therefore the damages could not have been solely for loss of contractual entitlement but must also have included damages for consequential loss.

103 All of the cases Lord Scott cites could potentially fall within the Ruxley category because in every breach of contract there is a loss of contractual entitlement. In Hayes $v$ James \& Charles Dodd (a firm), above n 26, his Lordship states recovery was ruled out because the loss was not foreseeable. Plainly it was, and as there is no other method of compensation available, and Lord Scott appears to think that Ruxley is applicable to consequential loss claims, it falls within Lord Scott's Ruxley criteria. 
even if "Ruxley" damages are accepted, the application of them is inconsistent with his statement of the rules. This blurring of the classification of loss leads to uncertainty.

To keep awards certain and principled it is necessary to distinguish a Ruxley or consumer surplus type award from consequential loss. As discussed earlier, under the Watts exception there is a critical distinction between a breach of contract with a mental benefit analogous to a condition, and a claim for consequential damage, being the harm flowing from the breach. A large amount of confusion, as shown earlier, is due to a failure to distinguish between the two types of cases. ${ }^{104}$ This is because consequential mental distress damages are technically not available, but courts nevertheless continue to award them. Thus, many of the "holiday" cases could be seen as either consequential loss or contractual entitlement, and many of them appear to award damages containing elements of both without distinguishing between them. It is respectfully submitted that Lord Scott's confusion of the classification of the cases stems from a desire to bring Farley under Ruxley, when in reality the case concerned consequential loss, not contractual entitlement. The true nature of Ruxley contractual entitlement damages can be illustrated by an examination of the award in that case.

The loss of amenity damages given in Ruxley were to compensate Mr Forsyth for getting a shallower pool than the one for which he had contracted. As Lord Scott states "it was not a case where the recovery of damages for consequential loss consisting of vexation, anxiety or other species of mental distress had to be considered."105 Mr Forsyth had just not received the end result that was promised to him. However, this loss of the promised pool was not reflected in its economic worth. Therefore, the loss of value was measured by reference to intangible loss. This could be viewed as damages for diminution in value or economic loss, albeit measured by reference to the loss of pleasure, as the normal measure was unavailable on the facts. This is fundamentally different to claims for consequential loss. One flows directly as a result of the breach. It is the deprivation of the actual contractual promise. The other loss is consequential to the breach. It is the extra loss that flows naturally on from it. These two types of awards are conceptually distinct. They are designed to compensate different types of loss. As a result, in cases where contractual entitlement damages are awarded it is theoretically possible to recover additional damages for consequential loss.

If Lord Scott was truly compensating for loss of contractual entitlement as he claims, any consequential mental distress could also be recovered as an additional loss flowing from the breach of contract. Therefore, Lord Scott's later statement that Mr Farley could not have recovered damages for economic loss and mental distress ${ }^{106}$ is inconsistent with his own reasoning. Even if

104 Farley v Skinner, above n 30, para 20 Lord Steyn.

105 Farley v Skinner, above n 30, para 80 Lord Scott.

106 Farley v Skinner, above n 30, para 109 Lord Scott. 
full reinstatement is awarded, consequential mental distress can be recovered in addition to that. ${ }^{107}$ This is because even though reinstatement removes the loss of bargain, the plaintiff has sustained extra damage because of the breach of contract. It is only by compensating both the loss of bargain and the consequential loss that the plaintiff can truly be put in the position they would have been in had the contract been performed. For example, in Kemp $v$ Intasun, ${ }^{108}$ the plaintiffs were given substandard accommodation with the result that their holiday was ruined and the wife suffered an asthma attack. In such a case it must be possible to award damages for the loss of the holiday (the deprivation of their promised benefit), plus the consequential mental distress of the wife suffering an asthma attack, provided that such an event was reasonably foreseeable at the time the contract was entered into.

It is respectfully submitted that the explanation for Lord Scott's statement that compensation for economic and consequential loss would be double recovery, and the confusion in classifying the cases, is that in reality, he was awarding damages for consequential loss. This is, therefore, yet a further illustration of the problem demonstrated earlier that the law is becoming confused by its failure to acknowledge that consequential mental distress damage should be compensated. Lord Scott's refusal to allow recovery for such damage on normal remoteness principles, whilst at the same time desiring to compensate Mr Farley's consequential distress is at the root of the problems in his speech. This approach does not address the underlying problem of the current unavailability of consequential damages for mental distress.

Given the fundamental difference of view between a small extension to the Watts "object" exception and Lord Scott's radical use of Ruxley, it is remarkable that Lord Browne-Wilkinson found himself able to agree with both Lord Steyn and Lord Scott. ${ }^{109}$

\section{B The Physical Inconvenience Exception}

In the writer's opinion this is where Farley really fell to be decided. All of their Lordships determined that Mr Farley was also entitled to recover under this exception. The confusing reasoning and application of the first exception in this case could easily have been avoided by awarding damages under the established exception for straightforward, foreseeable physical discomfort.

\section{A discretionary definition}

Lord Steyn added only a few comments as a postscript to his discussion on the first exception. He did not provide future courts with any clear guidance on when cases should fall under this

107 Harvey McGregor McGregor on Damages (17 ed, Sweet \& Maxwell, London, 2003) para 3-026.

108 Kemp v Intasun [1987] BTLC 353 (CA). The plaintiffs recovered damages for loss of enjoyment, but not for the wife's asthma attack which was too remote.

109 Farley v Skinner, above n 30, para 32 Lord Browne-Wilkinson. 
exception. This case did because noise can produce a physical reaction. He thought it was a matter of degree in each case. He further pointed out that noise could constitute a legal nuisance. ${ }^{110}$ It has been claimed this reference may be useful as it has the advantage of tapping into established case law. ${ }^{111}$ But why and how this helps is uncertain. It may be of use in some situations, but not in many. It is clear that this exception is obviously designed to cover situations outside of nuisance. In Hobbs, the plaintiff's walk home was obviously a physical inconvenience and falls squarely within this exception. However, there is no possibility of it falling under the tort of nuisance.

Lord Hutton likewise found it unnecessary to explain the exact scope of this category. He thought that damages were recoverable for physical inconvenience in this case because Mr Farley was affected through his hearing, which was obviously physical. The distinction he draws is between annoyance and disappointment, and actual physical discomfort and inconvenience. ${ }^{112}$ Lord Clyde took a similar approach. He remarked that there was no "particular magic in the word 'physical,"' and the category properly included cases of inconvenience which are more than matters of mere sentimentality. ${ }^{113}$ Therefore, the treatment of the second exception presents no great change to its original use in Hobbs, and whether a case falls under the exception is a largely discretionary matter to be left to the court.

Interestingly, Lord Clyde discussed Ruxley under the heading of physical inconvenience. Why he chose to do so is unclear. In Ruxley there was a separate award made for inconvenience that was so uncontroversial that it was not even mentioned in the House of Lords. ${ }^{114}$

\section{The sensory distinction}

Lord Scott would use the second exception in Watts to award damages for physical inconvenience, but only in cases where it is sensory. ${ }^{115}$ Given that "Ruxley" damages, as stated by him, cover all situations where there has been a loss of a contractual benefit, it would seem that this exception had been rendered redundant on his approach. ${ }^{116}$ Nevertheless, according to his Lordship cases of physical inconvenience are to be analysed under remoteness principles in the light of Watts. The sensory distinction does not appear to present a major change to the existing exception as stated

110 Farley v Skinner, above n 30, para 30 Lord Steyn.

111 McKendrick and Graham, above n 85, 165.

112 Farley v Skinner, above n 30, para 58 Lord Hutton.

113 Farley v Skinner, above n 30, para 35 Lord Clyde.

114 McKendrick and Graham, above n 85, 166.

115 Farley $v$ Skinner, above n 30, para 85 Lord Scott.

116 Given that his Lordship appears to think that Ruxley loss of contractual entitlement damages applies to consequential loss, all types of loss could be compensated under Ruxley. For a criticism of this see above Part IV A 2 The Ruxley Approach. 
by Bingham LJ. It is hard to imagine a case involving a physical reaction that is unable to be classified as sensory.

\section{The Implications of Farley}

As illustrated above, it would appear that Farley takes us no closer to a principled approach to damages for mental distress. Indeed it has been said that "a close examination of all four speeches in Farley can make your head spin."117 The decision, on the approach of all the Law Lords, still leaves simple consequential mental distress uncompensated.

Most importantly, Lord Scott's approach is ambiguous and confusing. Given the failure to recognise the fundamental difference between warranties and duties of care in the case, decisions which may follow this approach are given little in the way of firm guidance as to how to apply so called "Ruxley" damages. Despite academic support, ${ }^{118}$ it is respectfully submitted that Lord Scott's speech is internally contradictory and contrary to established principles and should not be followed. Further his speech is not, as it has been suggested, "a fuller statement of their Lordships' reasons"; 119 it is a fundamentally different approach.

The result of the case appears to be a small extension of the first Watts exception, under the approach of Lords Steyn, Clyde and Hutton, to include cases where pleasure or peace of mind is an important part of the contract, although not the very object. This approach should be welcomed, as it will allow for more cases to fall under this exception. However, the distinction it draws between cases where a major or important object of the contract is pleasure or peace of mind and claims of consequential loss is unprincipled. Further, recovery for consequential mental distress remains unavailable unless it stems from physical inconvenience, and so results will continue to be arbitrary and principles strained.

\section{CONCLUSION}

The law relating to mental distress damages remains in a chaotic and uncertain state. Not only are the rules so uncertain that it is hard to identify their content, but the approach being utilised is unprincipled and creates unfair results. It is hard to understand why any special rules are necessary in the area, given the problems they are causing. Rules are necessary to provide certainty, but when they begin to create inconsistency and perpetuate injustice, then their validity and usefulness must be questioned.

It would be a more honest and principled approach for the courts to allow damages for consequential mental distress on the usual remoteness tests, whilst at the same time acknowledging

117 Andrew J Bowen "Watts v Morrow and the Consumer Surplus" (2003) 1 SLT 1, 6.

118 Capper, above n 86.

119 Capper, above n 86, 196. 
the need for such awards to be modest. Until it is recognised that mental distress is a real loss deserving of compensation there will continue to be confusion as the courts struggle to find a way around Addis to achieve just results. The law in this area is unacceptable. It does not provide just results. In practice it does not treat all plaintiffs the same, and the reasoning is illogical and flawed.

Unfortunately, the House of Lords in Farley declined to take the approach suggested, and as a result the decision does not bring the law any closer to a coherent resolution. A concern to endorse Ruxley and to uphold Watts caused confusion and resulted in only a minor extension to the exceptions. The approach of Lord Scott, with respect, is likely to cause further confusion. The speech is internally contradictory and out of line with established principles of damages law. It should not be followed in New Zealand.

It is to be hoped that the New Zealand Supreme Court will have occasion to rule on a suitable case in the near future. However, it is respectfully submitted that the Court would be better to depart from English jurisprudence and attempt to create its own approach. A return to normal, wellestablished damages principles, doing away with Addis and the need for technical exceptions, would see the end of many of the problems in this area. Only then will it be possible for consistent and principled judgments that fully compensate true loss and put plaintiffs in the position they would have been in had the contract been performed. 